\title{
$\beta 2$-agonists promote host defense against bacterial infection in primary human bronchial epithelial cells
}

\author{
Claire A Gross ${ }^{\dagger 1}$, Russell P Bowler ${ }^{+1,2}$, Rebecca M Green ${ }^{1}$, Andrew R Weinberger ${ }^{1}$, Christina Schnell ${ }^{1}$ and \\ Hong Wei Chu*1,2
}

\begin{abstract}
Background: Airway epithelial cells are critical in host defense against bacteria including Mycoplasma pneumoniae (Mp) in chronic obstructive pulmonary disease (COPD) and asthma. $\beta 2$-agonists are mainstay of COPD and asthma therapy, but whether $\beta 2$-agonists directly affect airway epithelial host defense functions is unclear.

Methods: Epithelial cells from bronchial brushings of normal $(n=8)$, asthma $(n=8)$ and $\operatorname{COPD}(n=8)$ subjects were grown in air-liquid interface cultures, and treated with cigarette smoke extract (CSE) and/or Th2 cytokine IL-13, followed by Mp infection and treatment with $\beta 2$-agonists albuterol and formoterol for up to seven days. Mp and host defense proteins short palate, lung, and nasal epithelial clone 1 (SPLUNC1) and $\beta$-defensin- 2 were quantified. Expression of $\beta 2$-adrenergic receptors was also measured by real-time quantitative RT-PCR.

Results: $(\mathrm{R})$ - or racemic albuterol and $(\mathrm{R}, \mathrm{R})$ - or racemic formoterol significantly decreased Mp levels in normal and asthma epithelial cells. Normal cells treated with Mp and (R)- or racemic albuterol showed an increase in SPLUNC1, but not in $\beta$-defensin-2. COPD cells did not respond to drug treatment with a significant decrease in $\mathrm{Mp}$ or an increase in SPLUNC1. IL-13 attenuated drug effects on Mp, and markedly decreased SPLUNC1 and $\beta 2$-adrenergic receptors.
\end{abstract}

Conclusions: These results for the first time show that $\beta 2$-agonists enhance host defense functions of primary bronchial epithelial cells from normal and asthma subjects, which is attenuated by IL-13.

\section{Background}

Bacterial infections are common in the airways of patients with chronic lung diseases [1-3]. As many as $40 \%$ of stable asthmatics test positive for atypical bacteria in airway samples[4]. Higher levels of pathogens such as Mycoplasma pneumoniae (Mp) and Chlamydia pneumoniae are associated with more severe asthma symptoms and increased COPD exacerbations[5,6]. Treatment with antibiotics such as clarithromycin can improve lung function in asthma patients with Mp[7]. However, bacterial infections remain prevalent in patients with chronic lung diseases, suggesting impaired lung host defense functions in these patients.

\footnotetext{
* Correspondence: chuhw@njhealth.org

1 Department of Medicine, National Jewish Health, 1400 Jackson Street, Denver, Colorado, 80206, USA

+ Contributed equally

Full list of author information is available at the end of the article
}

Innate immune response in airway epithelial cells provides a vital source of host defense molecules to protect against respiratory infection. For example, large airway epithelial cells constitutively produce short palate, lung, and nasal epithelium clone 1 (SPLUNC1), a member of the PLUNC protein family, which is proposed to exhibit host defense properties[8]. SPLUNC1 has been shown to possess antimicrobial and anti-inflammatory functions $[9,10]$. Bacterial infection increases SPLUNC1 levels. However, in an allergic setting including the Th2 cytokine IL-13, SPLUNC1 levels and Mp clearance are decreased[10]. Human $\beta$-defensins (h $\beta$ Ds) are another class of antimicrobial proteins produced by epithelial cells of airways and skin, and are able to kill a broad spectrum of bacteria including $\mathrm{Mp}[11]$. $\mathrm{h} \beta \mathrm{D}-3$, closely related to $h \beta D-2$, is shown to be down-regulated by IL-13[12].

$\beta 2$-agonists are the mainstay of therapy to induce bronchodilation in patients suffering from COPD and asthma. 
The drugs work through $\beta 2$-adrenergic receptors to exert their functions including relaxation in smooth muscle cells[13]. The receptors are expressed in various types of cells in the lung including airway epithelial cells[14]. In addition to their bronchodilatory effect, $\beta 2$-agonists have been shown to reduce the production of inflammatory cytokines and thereby airway inflammation[15]. Moreover, $\beta 2$-agonist salmeterol was shown to protect airway epithelial integrity that was otherwise impaired by Pseudomonas aeruginosa exoproducts[16]. Interestingly, activation of $\beta 2$-adrenergic receptors on human peripheral blood $\mathrm{T}$ cells could modulate production of Th2 cytokines (e.g., IL-13)[17]. In our previous studies, IL-13 was able to increase bacterial (e.g., mycoplasma) load in airway epithelial cells[10]. These publications suggest that $\beta 2$-agonists may modulate airway epithelial cell host defense functions. However, there is a lack of direct evidence demonstrating host defense functions of $\beta 2$-agonists in primary human airway epithelial cells.

Extended use of exogenous antibiotics may cause drug resistance, thereby becoming less effective at eliminating chronic infections that are prevalent in COPD and asthma patients. Therefore, it is beneficial to enhance airway production of endogenous antimicrobial substances to promote the clearance of invading bacteria. In this study, we seek to identify a novel function of the shortand long-acting $\beta 2$-agonists albuterol and formoterol, in (R)-, (R,R)-, racemic, (S)-, or (S,S)-isomeric forms, which have different efficacies in bronchodilation [18-20]. Specifically, we hypothesize that $\beta 2$-agonists possess an antimicrobial function by decreasing bacterial levels in primary human bronchial epithelial cells from normal subjects, asthmatics, and COPD patients. We predict that they do so in part through the induction of host defense molecules SPLUNC1 and h $\beta \mathrm{D}-2$.

\section{Methods \\ Study participants, bronchoscopy, and bronchial epithelial cell processing}

Bronchoscopy with endobronchial epithelial brushings was performed on 24 human subjects (normal $=8$, asthma $=8, C O P D=8$ ). The clinical characteristics for all subjects are shown in Table 1. Four of the normal subjects were non-smokers and four were healthy smokers. Asthmatics met the American Thoracic Society (ATS) criteria for mild to moderate asthma. COPD patients had Global Initiative for COPD (GOLD) stages between II and IV. Bronchial brushings were performed as previously described[21] with a single-sheathed cytology brush (\#CF-001, Medical Engineering Laboratory, Durham, NC). Up to six brushings were obtained per subject. Our research protocols were approved by the institutional review board at National Jewish Health, and all subjects provided written informed consent.
Primary bronchial epithelial cell air-liquid interface cultures Brushed bronchial epithelial cells were seeded onto 60 $\mathrm{mm}$ collagen-coated tissue culture dishes, and incubated at $37^{\circ} \mathrm{C}$ with $5 \% \mathrm{CO}_{2}$ (Figure 1 ). At $80 \%$ confluence, they were transferred onto collagen-coated transwell inserts (4 $\times 10^{4}$ cells/insert) in 12-well plates[21]. After reaching confluence under the submerged condition, they were shifted to air-liquid interface (ALI), and treated with or without IL-13 $(10 \mathrm{ng} / \mathrm{ml})$ and/or $20 \%$ cigarette smoke extract (CSE) to mimic the airways of asthmatics and smokers with or without COPD. IL-13 concentration was chosen based on previous publications in human airway epithelial cell cultures[10,21-23], and measurement of IL13 protein in bronchoalveolar lavage fluid of asthmatics with a segmental allergen challenge[24]. Medium, IL-13, and/or CSE were replenished every 48 hours for 10 days to allow cell mucociliary differentiation. Cells were then infected with $\mathrm{Mp}$ and treated with (R)-, racemic, or (S)albuterol $(10 \mu \mathrm{M})$, or $(\mathrm{R}, \mathrm{R})$-, racemic, or $(\mathrm{S}, \mathrm{S})$-formoterol $(10 \mathrm{nM})$ as shown in Table 2. $\beta 2$-agonists were provided by the Sepracor, Inc (Marlborough, MA). The concentration of albuterol or formoterol was chosen based on previous publications in human airway epithelial cell cultures, and was consistent with the dose of effective therapy in humans [25-30]. On days 1,3 , and 7 post-Mp infection, an aliquot of apical supernatant was plated onto PPLO agar plates for $\mathrm{Mp}$ quantification. The remainder was stored at $-80^{\circ} \mathrm{C}$ for quantification of SPLUNC1 and h $\beta D-2$ by ELISA. Seven days post-infection, cells were harvested into TRIzol (Invitrogen) for total RNA extraction.

\section{Cigarette smoke extract (CSE) preparation}

CSE was prepared daily as previously described with slight modifications[31]. Mainstream cigarette smoke was bubbled into $12.5 \mathrm{ml}$ of serum-free cell culture medium. The medium was filter-sterilized, diluted in cell culture medium to $20 \%$, and applied to the apical side of the transwells within 30 minutes of preparation.

\section{Mp preparation and culture}

Mp was prepared for cell culture as previously described[10]. To quantify Mp, PPLO agar plates with epithelial apical supernatant were incubated at $37^{\circ} \mathrm{C}$ with $5 \% \mathrm{CO}_{2}$ for seven days for colony forming unit (CFU) counting.

\section{Direct effects of $\beta 2$-agonists on bacterial load in an epithelial cell-free environment}

To determine if $\beta 2$-agonists can directly affect bacterial growth, (R)-, racemic, (S)-albuterol $(10 \mu \mathrm{M})$ or $(\mathrm{R}, \mathrm{R})$-, racemic and $(\mathrm{S}, \mathrm{S})$-formoterol $(10 \mathrm{nM})$ or PBS (control) was incubated in quadruplicate with $\mathrm{Mp}\left(4 \times 10^{4} \mathrm{CFU}\right.$ per well, the same number of bacteria as plated on airway 
Table 1: Characteristics of human study subjects

\begin{tabular}{lllllll}
\hline & Age & $\begin{array}{l}\text { Sex } \\
\text { (M/F) }\end{array}$ & $\begin{array}{l}\text { Smoking } \\
\text { (pack-years) }\end{array}$ & $\begin{array}{l}\text { FEV1, \% } \\
\text { predicted }\end{array}$ & $\begin{array}{l}\text { FVC, \% } \\
\text { predicted }\end{array}$ & FEV1/FVC\% \\
\hline $\begin{array}{l}\text { Normal } \\
(\mathrm{n}=8)\end{array}$ & $52.3 \pm 4.3$ & $4 / 4$ & $\mathbf{4}-0$ & $97.5 \pm 6.8$ & $92.0 \pm 6.9$ & $82.8 \pm 1.3$ \\
$\begin{array}{l}\text { COPD } \\
(\mathrm{n}=8)\end{array}$ & $66.8 \pm 1.8$ & $3 / 5$ & $\mathbf{4}-37.0 \pm 4.1$ & & $61.4 \pm 7.9$ & $46.6 \pm 6.7$ \\
$\begin{array}{l}\text { Asthma } \\
(\mathrm{n}=8)\end{array}$ & $48.8 \pm 7.5$ & $4 / 4$ & $\mathbf{8}-67.8 \pm 10.8$ & $38.5 \pm 7.7$ & & \\
\hline
\end{tabular}

$\mathrm{FEV}_{1}$, forced expiratory volume in the $1^{\text {st }}$ second; FVC, forced vital capacity.

epithelial cells) in a cell-free 96-well plate. After 2 hours (a typical time for bactericidal assay), the supernatants were plated on PPLO agar plates to quantify the bacterial level.

\section{SPLUNC1 and h $\beta D-2$ ELISAs}

Our previously developed direct SPLUNC1 ELISA was performed on the epithelial apical supernatants to quantify SPLUNC1[10].

$\mathrm{h} \beta \mathrm{D}-2$ levels in the apical supernatants were determined with an ELISA kit (PeproTech, Rocky Hill, NJ). The plate was coated with a capture antibody (Ab), blocked with BSA, and then incubated with apical supernatant, detection $\mathrm{Ab}$ and avidin-HRP. The plate was developed with 2,2'-Azino-bis(3-ethylbenzothiazoline-6sulfonic acid).

\section{Real-time quantitative PCR}

Reverse transcription and real-time PCR were used to determine the effect of IL-13 on mRNA expression of the $\beta 2$-adrenergic receptor (ADRB2). $1 \mu \mathrm{g}$ of total RNA was reverse transcribed with Oligo DT in a $50 \mu \mathrm{l}$ reaction. A Taqman Gene Expression Assay (Applied Biosystems, Foster City, CA) was used to measure ADBR2 mRNA relative levels using the comparative threshold cycle $\left(\mathrm{C}_{\mathrm{T}}\right)$ method by normalizing to the housekeeping gene GAPDH (Applied Biosystems)[21].

\section{Statistical analysis}

One-way analysis of variance (ANOVA) was used for multiple comparisons, and a Tukey's post hoc test was applied where appropriate. Student's $t$ test was used when only two groups were compared. A p value $\leq 0.05$ was considered significant.

\section{Results}

Impact of $\beta 2$-agonists on airway epithelial bacterial load and SPLUNC1 levels in the absence of IL-13

All data presented is the average of the same conditions at days 1,3 , and 7 because the trends were consistent across all three-time points. We analyzed the data in smokers and non-smokers in each subject group, and did not observe any significant differences of Mp levels. Therefore, we combined the data from smokers and non-smokers for further analysis.

To evaluate the overall cell responses to $\beta 2$-agonists, we performed an initial data analysis in all 24 subjects from the three subject groups. (R)-albuterol, racemic albuterol, $(\mathrm{R}, \mathrm{R})$-formoterol, and racemic formoterol significantly reduced $\mathrm{Mp}$ levels in the apical supernatants from cells

Table 2: Air-liquid interface culture conditions $(n=56)$ of human primary brushed bronchial epithelial cells from normal subjects and patients with asthma and COPD

\begin{tabular}{|c|c|c|c|c|c|c|c|c|}
\hline Drug & Medium & CSE & $\begin{array}{c}\text { CSE + } \\
\text { Mp }\end{array}$ & IL-13 & $\begin{array}{c}\text { IL-13 + } \\
\text { CSE }\end{array}$ & $\begin{array}{c}\text { IL-13 + CSE } \\
\text { + Mp }\end{array}$ & $\begin{array}{c}\mathrm{IL}-13+ \\
\mathrm{Mp}\end{array}$ & Mp \\
\hline No drug & $x$ & $x$ & $x$ & $x$ & $x$ & $x$ & $x$ & $x$ \\
\hline (R)-albuterol & $x$ & $x$ & $x$ & $x$ & $x$ & $x$ & $x$ & $x$ \\
\hline Racemic albuterol & $x$ & $x$ & $x$ & $x$ & $x$ & $x$ & $x$ & $x$ \\
\hline (S)-albuterol & $x$ & $x$ & $x$ & $x$ & $x$ & $x$ & $x$ & $x$ \\
\hline$(\mathrm{R}, \mathrm{R})$-formoterol & $x$ & $x$ & $x$ & $x$ & $x$ & $x$ & $x$ & $x$ \\
\hline $\begin{array}{l}\text { Racemic } \\
\text { formoterol }\end{array}$ & $x$ & $x$ & $x$ & $x$ & $x$ & $x$ & $x$ & $x$ \\
\hline$(\mathrm{S}, \mathrm{S})$-formoterol & $x$ & $x$ & $x$ & $x$ & $x$ & $x$ & $x$ & $x$ \\
\hline
\end{tabular}

CSE, cigarette smoke extract; Mp, Mycoplasma pneumoniae. 


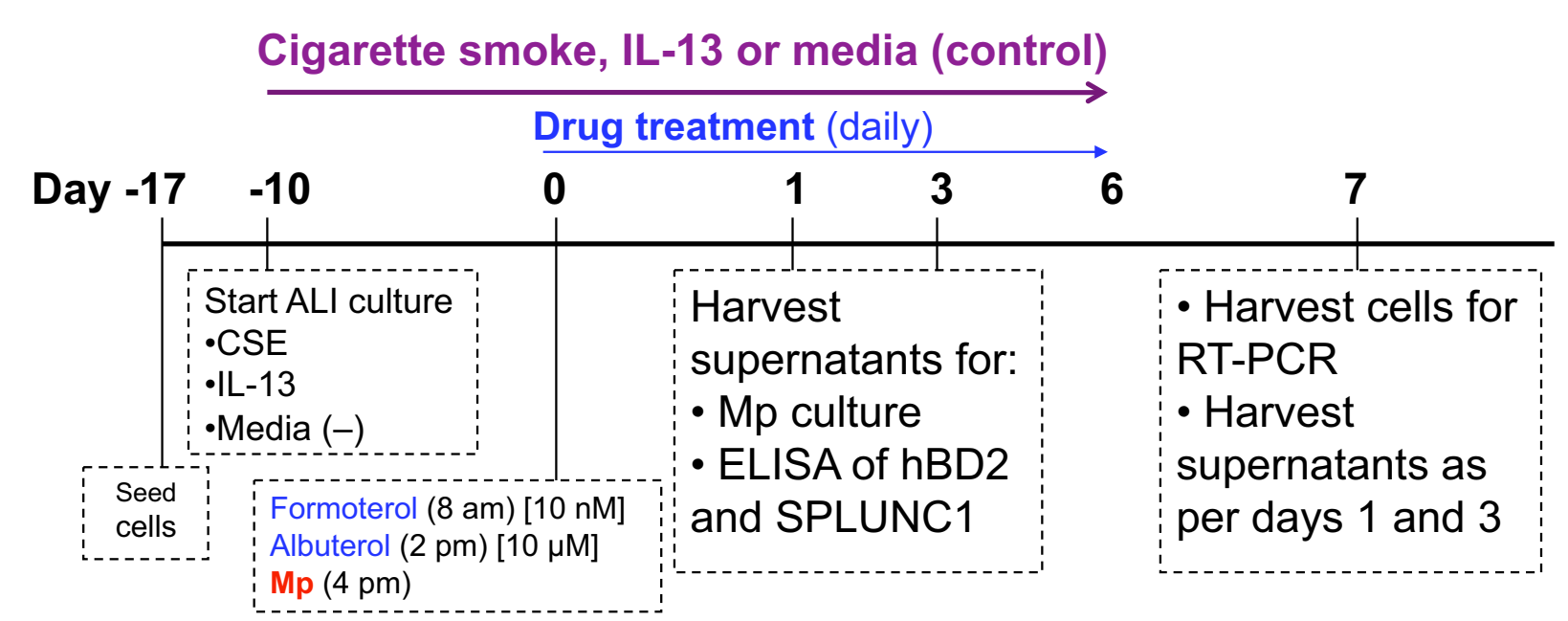

Figure 1 Timeline of primary human bronchial epithelial cell air-liquid interface (ALI) cultures. Cells were seeded in transwells in immersed culture for 7 days to allow cell proliferation, and then were shifted to ALI for 10 days to induce mucociliary differentiation. Cigarette smoke extract (CSE) and/or IL-13 treatment began with the ALI condition. At day 10, cells were treated with drug and infected with Mycoplasma pneumoniae (Mp). Apical supernatants were harvested at days 1,3, and 7 post-infection, and cells were harvested at day 7 for mRNA analysis of gene of interest using real-time RT-PCR. SPLUNC1 = short palate, lung, and nasal epithelial clone 1; and hBD2 = human $\beta$-defensin-2.

treated with Mp (Figure 2A) or Mp + CSE (Figure 2B) as compared to cells not treated with any drug. (S)-albuterol and (S,S)-formoterol did not significantly alter Mp load (data not shown).

Differences in the drug effect on Mp load existed between subject groups. Among cells treated with $\mathrm{Mp}$ or $\mathrm{Mp}+\mathrm{CSE}$, normal subjects showed the strongest drug effect of decreased Mp burden, including significant ( $\mathrm{p}<$ $0.05)$ reduction of Mp levels in four conditions ( $(R)$ albuterol+Mp, (S)-albuterol+Mp, (R,R)-formoterol $+\mathrm{Mp}+\mathrm{CSE}$, and (S,S)-formoterol+Mp), as compared to non-drug-treated cells. Asthmatics showed a moderate trend, also with some significant $(\mathrm{p}<0.05)$ decreases of Mp levels in three conditions ( $(\mathrm{R})$-albuterol $+\mathrm{Mp},(\mathrm{R}, \mathrm{R})$ formoterol $+\mathrm{Mp}$, and Rac-formoterol $+\mathrm{Mp})$. Cells from COPD patients exhibited the weakest trend for drug effect in decreasing Mp levels without statistical significance (Table 3).

In all subjects combined, SPLUNC1 levels were not significantly different with the addition of any of the drugs. However, cells from normal subjects treated with Mp plus either (R)- or racemic albuterol significantly increased SPLUNC1 levels in the apical supernatant (Figure 3). (R,R) - and racemic formoterol marginally increased SPLUNC1 ( $\mathrm{p}=0.1$ and $\mathrm{p}=0.07$, respectively). In addition, in Mp-infected normal subject cells, (S)albuterol trended $(\mathrm{p}=0.062)$ to increase SPLUNC1 protein levels. Cells from COPD and asthma patients did not show significantly increased SPLUNC1 following any drug treatment.
Impact of $\beta 2$-agonists on airway epithelial bacterial load and SPLUNC1 levels in the presence of IL-13

In sharp contrast to cells without IL-13 treatment, cells treated with IL-13 did not respond to any of the drugs with lower Mp levels. No clear trend of increase or decrease of Mp levels was present in the IL-13-treated cells with the addition of drug. Furthermore, overall Mp levels in IL-13 treated cells were significantly higher in all subjects combined (Figure 4A) or in any individual subject group (data not shown) compared to cells without IL13. Accordingly, IL-13 treated cells had significantly lower SPLUNC1 levels than those without IL-13 (Figure $4 \mathrm{~B})$.

\section{Direct effects of $\beta 2$-agonists on bacterial load in an epithelial cell-free environment}

Albuterol or formoterol of any isomers, as compared to PBS (negative control), did not ( $\mathrm{p}=0.78)$ affect Mp levels in an epithelial cell-free environment (Figure 5). These data suggest that $\beta 2$-agonists did not have a direct antibacterial (e.g., bactericidal) effect, and may exert their host defense activity through modulating airway epithelial cell functions.

\section{Impact of IL-13 on $\beta 2$-adrenergic receptor (ADRB2) mRNA Levels}

Since cells treated with IL-13 failed to respond to $\beta 2$-agonists, we determined if IL-13 reduced ADRB2 expression, rendering drug resistance. mRNA levels of ADRB2 were quantified in epithelial cells with or without IL-13 treatment. At baseline (no IL-13 treatment), bronchial epithe- 
A

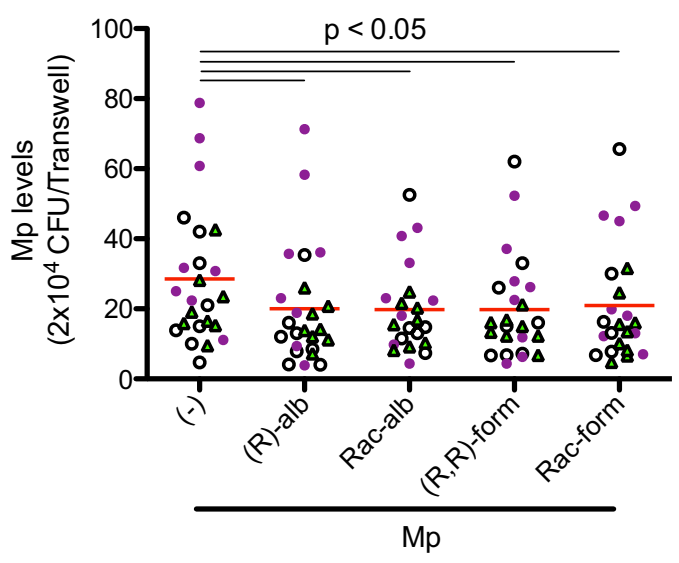

B

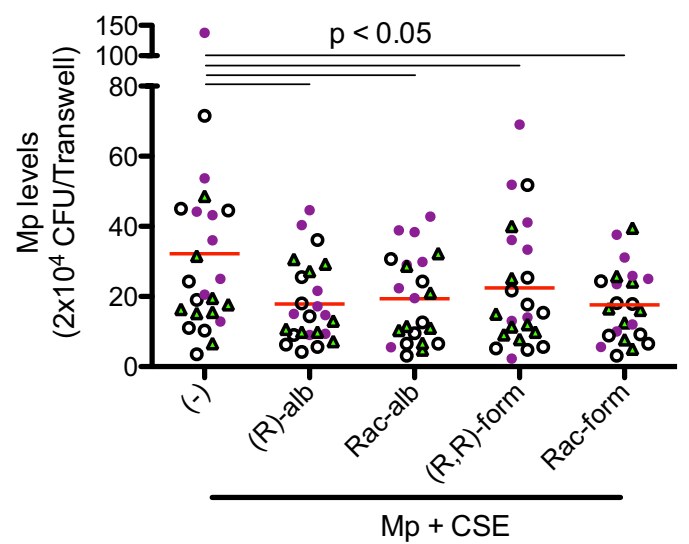

Figure 2 Quantification of Mycoplasma pneumoniae (Mp) in the apical supernatants of cultured bronchial epithelial cells. Cells from all three subject groups ( $n=24)$ were treated with various isomers of albuterol and formoterol in the presence of Mp only (1 CFU/cell) (A), or Mp (1 CFU/cell) + CSE (20\%) (B). Mp levels significantly decreased with by (R)-albuterol [(R)-alb], racemic albuterol [Rac-alb], (R,R)-formoterol [(R,R)-form], and racemic formoterol [Rac-form]. The red horizontal bars represent means of data under each cell culture condition. The open white circles indicate normal subjects; the closed purple circles indicate COPD patients; and the green triangles represent asthmatics.

lial cell ADRB2 mRNA levels were not $(\mathrm{p}=0.15)$ significantly different among normal subjects (ADRB2 mRNA relative level: $15.0 \pm 2.5)$, asthmatics $(8.6 \pm 2.3)$ and COPD patients $(13.8 \pm 2.3)$. Compared with the control (no IL-13), IL-13 treatment significantly decreased ADRB2 mRNA expression in bronchial epithelial cells from asthma (Figure 6A) and COPD patients (Figure 6B). However, IL-13 did not significantly $(\mathrm{p}=0.12)$ reduce ADRB2 mRNA levels in normal cells.

\section{Impact of $\beta 2$-agonists on $\mathrm{h} \beta \mathrm{D}-2$ levels}

$\mathrm{h} \beta \mathrm{D}-2$ was measured to explain reduced Mp levels following $\beta 2$-agonist treatment in epithelial cells. However, unlike the Mp or SPLUNC1 data, no significant differ- ences were found in $\mathrm{h} \beta \mathrm{D}-2$ levels among any drug treatments, including samples with or without IL-13.

\section{Discussion}

In the current study, we demonstrated a novel host defense function for the short- and long-acting $\beta 2$-agonists albuterol and formoterol in primary brushed human bronchial epithelial cells. We found that the drugs were capable of lowering the Mp burden (up to $40 \%$ reduction) of epithelial cells, and that they appeared to do so in part through the induction of SPLUNC1, especially in normal subjects. However, in the COPD cells and in all the cells treated with IL-13, this drug effect was abolished, possibly through the reduction of SPLUNC1 and $\beta 2$-adrenergic receptor (ADRB2).

Table 3: Effects of $\beta 2$-agonist isomers on Mycoplasma pneumoniae (Mp) load in cultured human airway epithelial cells*

\begin{tabular}{llclccc}
\hline & \multicolumn{2}{c}{ Normal subjects } & \multicolumn{2}{c}{ Asthma } & & COPD \\
\hline & Mp & Mp + CSEt & Mp & Mp + CSE & Mp & Mp + CSE \\
\hline (R)-albuterol & $\mathbf{0 . 0 3}$ & 0.16 & $\mathbf{0 . 0 3}$ & 0.24 & 0.43 & 0.14 \\
Racemic albuterol & 0.14 & 0.09 & 0.08 & 0.10 & 0.08 & 0.16 \\
(S)-albuterol & $\mathbf{0 . 0 1}$ & 0.48 & 0.15 & 0.21 & 0.44 & 0.20 \\
(R,R)-formoterol & 0.17 & $\mathbf{0 . 0 3}$ & $\mathbf{0 . 0 4}$ & 0.10 & 0.07 & 0.15 \\
Racemic formoterol & 0.48 & 0.10 & $\mathbf{0 . 0 1}$ & 0.37 & 0.13 & 0.08 \\
(S,S)-formoterol & $\mathbf{0 . 0 1}$ & 0.25 & 0.77 & 0.55 & 0.64 & 0.24 \\
\hline
\end{tabular}

*, Data are presented as $p$ values. A p value $\leq 0.05$ is considered statistically significant. The $p$ values were obtained by comparing $\beta 2$-agonists with no drug treatments. + , CSE $=$ cigarette smoke extract. 


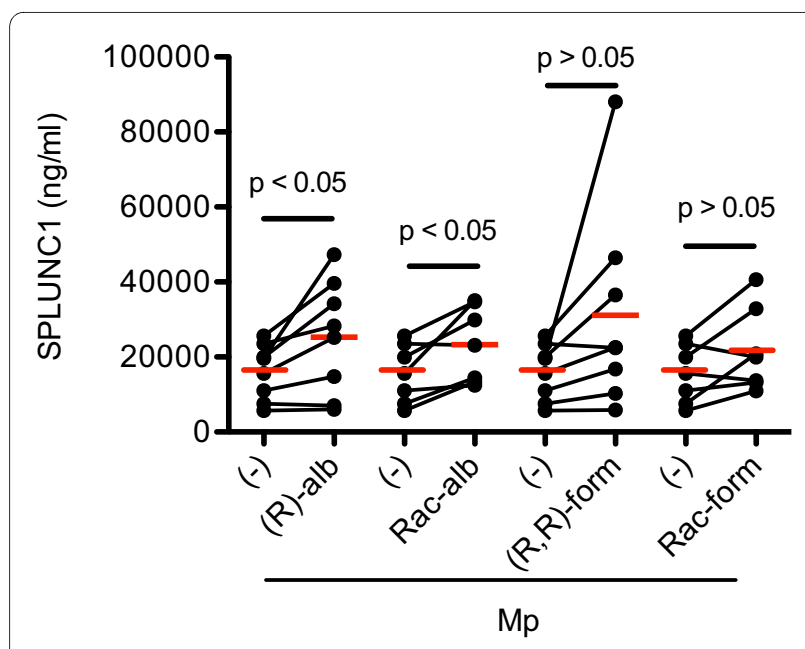

Figure 3 SPLUNC1 protein levels in the apical supernatants of cultured bronchial epithelial cells. Cells from normal subjects $(n=8)$ were treated with Mycoplasma pneumoniae (Mp, 1 CFU/cell). Both (R)albuterol [(R)-alb] and racemic albuterol [Rac-alb] significantly increased SPLUNC1 levels. (R,R)-formoterol [(R,R)-form] and racemic formoterol [Rac-form] marginally increased SPLUNC1. The red horizontal bars represent means of data under each cell culture condition.

Host defense function of $\beta 2$-agonists in the absence of IL13

A certain population of asthmatics has no or very low Th2 cytokine background[32,33]. Therefore, testing the effects of $\beta 2$-agonists without IL-13 is relevant for this subset of patients. (R)- and racemic albuterol and (R,R)and racemic formoterol were found to reduce Mp levels in human bronchial epithelial cells mainly from normal subjects and/or asthmatics without IL-13 treatment. Our results suggest that $\beta 2$-agonists enhance host defense functions in the airway mucosa. This decrease was significant with all 24 subjects combined in both Mp-only and $\mathrm{Mp}+\mathrm{CSE}$ conditions. When data were analyzed in indi-

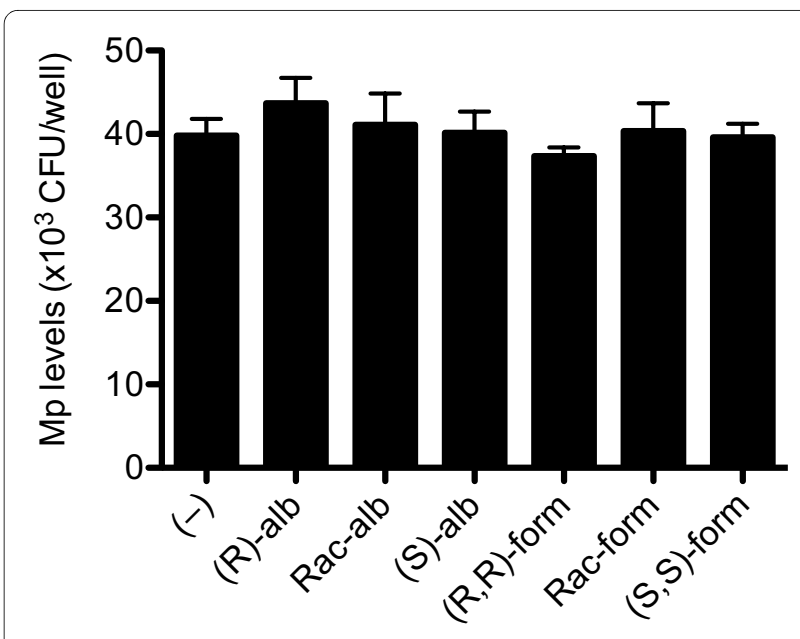

Figure 5 Mycoplasma pneumoniae (Mp) levels in the supernatants of a cell-free 96 -well plate. Various isomers of albuterol (10 $\mu \mathrm{M})$ and formoterol $(10 \mathrm{nM})$ or PBS (control, (-)) were incubated in quadruplicate with $\mathrm{Mp}\left(4 \times 10^{4} \mathrm{CFU}\right.$ per well) for 2 hours. Mp levels did not ( $p$ $=0.78$ ) significantly change following treatments with (R)-albuterol [(R)-alb], racemic albuterol [Rac-alb], (S)-albuterol [(S)-alb], (R,R)-formoterol $[(R, R)$-form], racemic formoterol [Rac-form] or $(S, S)$-formoterol $[(\mathrm{S}, \mathrm{S})$-form $]$.

vidual groups of subjects, the cells from the three subject groups responded differently to drug treatment following $\mathrm{Mp}$ infection. A previous study shows that mucin MUC5AC mRNA and protein levels can be differentially regulated in normal versus asthmatic brushed bronchial epithelial cells ex vivo[34]. The current study finds COPD cells responded less effectively to $\beta 2$-agonists compared with normal and asthmatic cells. In response to $\beta 2$-agonists, the normal cells had the lowest bacterial load; asthmatic cells also had significantly lower Mp burden. However, the COPD cells showed only a slight trend of decrease in Mp levels. Overall, the COPD cells carried a
A

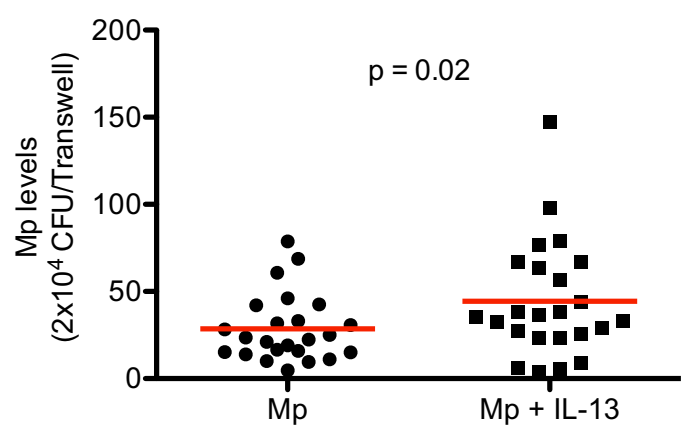

B

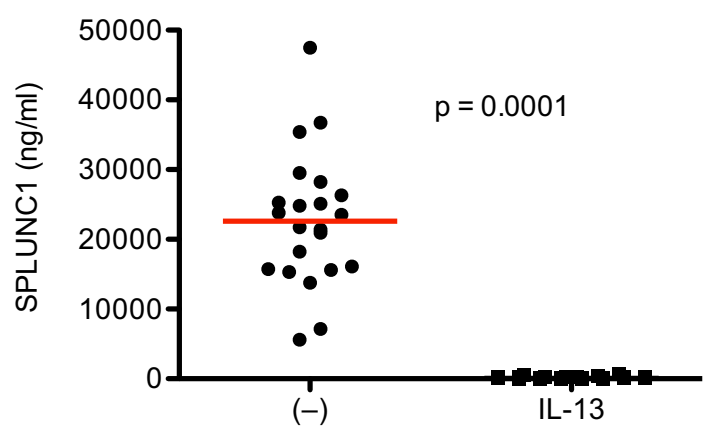

Figure 4 Quantification of Mycoplasma pneumoniae (Mp) and SPLUNC1 protein levels in the apical supernatants of bronchial epithelial cells. Cells from all three subject groups $(\mathrm{n}=24)$ were treated with $\mathrm{Mp}$ in the presence or absence of IL-13 $(10 \mathrm{ng} / \mathrm{ml})$. IL-13 treatment significantly increased Mp levels (A), but dramatically decreased SPLUNC1 levels (B). The red horizontal bars represent means of data under each cell culture condition. 
A

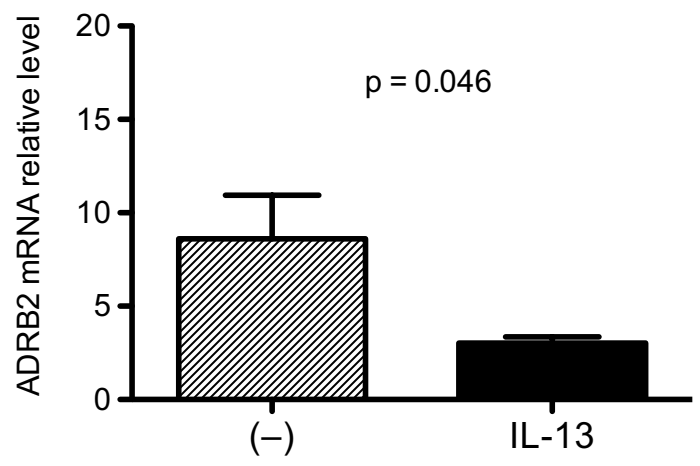

B

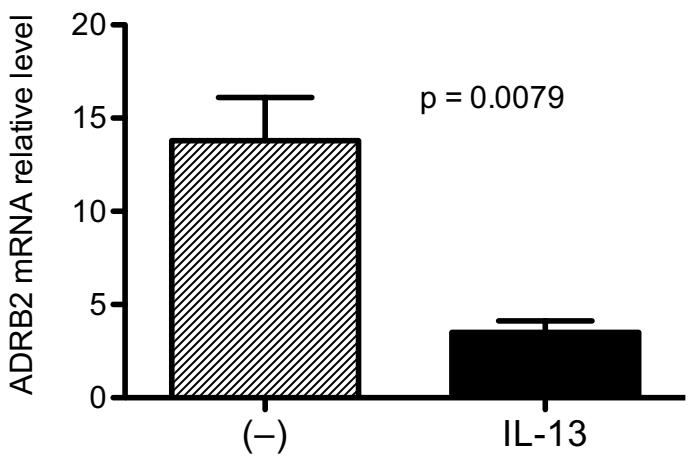

Figure 6 Impact of IL-13 on $\beta$ 2-adrenergic receptor (ADRB2) mRNA expression in bronchial epithelial cells. Compared with non-IL-13 treatment (-), IL-13 significantly lowered ADRB2 mRNA levels in cultured bronchial epithelial cells from asthma $(\mathbf{A}, n=8$,$) and \operatorname{COPD}(\mathbf{B}, n=8)$ patients.

higher Mp burden than normals or asthmatics, suggesting that the COPD cells had inherently suppressed host defense against $\mathrm{Mp}$ as compared to the other groups. For example, in the current study, we found that baseline SPLUNC1 levels in apical supernatants of airway epithelial cells from COPD patients $(18073 \pm 2577 \mathrm{ng} / \mathrm{ml})$ trended to be lower than those from normal subjects $(24631 \pm 2676 \mathrm{ng} / \mathrm{ml}, \mathrm{p}=0.14)$ and asthmatics $(25020 \pm$ $4480 \mathrm{ng} / \mathrm{ml}, \mathrm{p}=0.22$ ).

While the racemic isomers of $\beta 2$-agonists are used clinically, the (R)- and (R,R)- isomers are known to be the drugs' active forms. Application of (S)-albuterol and $(\mathrm{S}, \mathrm{S})$-formoterol resulted in reduced Mp load only in normal cells, but not cells from asthmatics and COPD patients. (S)-albuterol has traditionally been thought to be inert, but studies have shown that the (S)-isomer may actually increase inflammation and negate the antiinflammatory effects of $(\mathrm{R})$-albuterol[18,19]. It is therefore not surprising to observe differing antimicrobial effects of (S)- and (S,S)-isomers in cells from various study groups (e.g., normal subjects versus asthma and COPD patients). The mechanisms by which (S)- or (S,S)isomers differ from (R)- or (R,R)-isomers in reducing bacterial levels remain unclear, and will be addressed in our future studies. For example, a $\beta 2$-receptor antagonist can be used to test whether different isomers act similarly through $\beta 2$-receptors.

How $\beta 2$-agonists increase airway epithelial host defense functions remains unclear. Our data demonstrate that albuterol resulted in an increase in secreted SPLUNC1 levels in normal cells treated with $\mathrm{Mp}$ alone. This corresponded to the decrease in Mp burden seen in these cells. However, no significant increase of SPLUNC1 existed in the cells treated with both Mp and CSE. Further, there was only a slight induction of SPLUNC1 fol- lowing drug treatment in the asthma cells and none in the COPD cells. These data indicate that the heightened host defense can be explained in part, but not entirely, through increased SPLUNC1 levels, particularly in normal cells. Conversely, no significant differences were detected in $h \beta D-2$ levels in any of the conditions, suggesting that $\mathrm{h} \beta \mathrm{D}-2$ may not contribute to increased host defense through $\beta 2$-agonists. Other mechanisms may also contribute to the beneficial effects of $\beta 2$-agonists on airway epithelial defense against bacterial infection. For example, Hasani and colleagues demonstrated that albuterol treatment in COPD patients enhanced lung mucociliary clearance[35], but whether this is linked to less bacterial load in the lung was not investigated. Moreover, long-acting $\beta 2$-agonist salmeterol was shown to attenuate Pseudomonas aeruginosa-induced mucosal damage in cultured human nasal turbinate tissue[36]. Future studies are warranted to: (1) further explore the mechanisms by which albuterol or formoterol exerts host defense functions. These include, but are not limited to, studies aimed at dissecting the involvement of $\beta 2$-adrenergic receptor vs. other receptors such as platelet-activating factor (PAF) receptor and $\beta 1$-adrenergic receptor[37]; and (2) determine if $\beta 2$-agonists are able to reduce lung bacterial load in COPD patients, especially those with acute exacerbations.

We are aware that our results in human cells do not support those of a mouse study conducted by Maris and colleagues[38], who found worsened clearance of nontypeable Haemophilus influenzae with salmeterol treatment in mice. Several differences exist between the two studies, including the types of cells cultured in vitro (primary human bronchial epithelial cells versus mouse alveolar macrophage cell line MH-S), the bacteria studied (atypical bacteria versus gram negative bacteria), and the 
drugs used. Therefore, a more systematic human study is needed to further investigate the in vivo effects of $\beta 2$-agonists on airway mucosal innate immunity. We also realize that the concentration of albuterol in our study may be high. Future studies are needed to accurately measure the concentration of albuterol in airway epithelial lining fluid of human subjects who receive albuterol, especially the more active R-isomer.

\section{Host defense function of $\beta 2$-agonists in the presence of IL-} 13

Because a Th2 cytokine milieu exists in both asthma and COPD, it is important to determine if $\beta 2$-agonists in the presence of a Th2 cytokine such as IL-13 function as efficiently as in the absence of a Th2 cytokine. IL-13 was shown to dampen epithelial cells' host defense response, as overall Mp levels were higher in the IL-13-treated cells than those without IL-13. To explore the underlying mechanisms for the loss of effect of $\beta 2$-agonists in IL-13treated cells, we measured SPLUNC1 levels. We found that SPLUNC1 levels in the IL-13 treated cells were markedly lower than those in non-IL-13 treated cells, suggesting that the presence of IL-13 suppressed cells' ability to clear bacteria. None of the drugs lowered Mp levels in this condition. Therefore, IL-13 attenuated the effects of $\beta 2$-agonists on lowering Mp levels. To further investigate the mechanism by which IL-13 inhibited host defense, we quantified the mRNA levels of ADRB2 from samples cultured with and without IL-13. Treatment with IL-13 significantly reduced ADRB2. This may provide an additional explanation why the IL-13-treated cells did not show any significant drug effect. Our results, for the first time, provide evidence that a Th2 cytokine IL-13 can significantly decrease ADRB2 expression. This may have clinical implications to improve the efficacy of $\beta 2$-agonist therapy. For example, a therapy such as corticosteroid treatment, aimed at reducing the Th2 cytokine production or activity will be required to improve the antimicrobial efficacy of $\beta 2$-agonists in both asthma and COPD patients.

\section{Conclusions}

The goal of current study was to examine if $\beta 2$-agonists, the mainstay of therapy in COPD and asthma, exert host defense functions in airway mucosa. We found that in normal bronchial epithelial cells without exposure to a Th2 cytokine IL-13, $\beta 2$-agonists albuterol and formoterol decrease Mp load. The antimicrobial effect of albuterol may be in part through the induction of SPLUNC1 from airway epithelial cells, but not through its direct bactericidal activity on Mp. This effect is attenuated in COPD cells and particularly by IL-13 treatment. Future studies are needed to determine whether the use of a corticosteroid in addition to the $\beta 2$-agonist can rescue the host defense functions of airway epithelial cells in COPD cells and in cells with IL-13 treatment. The combination of a long-acting $\beta 2$-agonist with a corticosteroid may be most beneficial for enhancing endogenous host defense functions of airway epithelial cells in COPD and asthma patients with a Th2 cytokine background. Additionally, it may be possible to increase the ADRB2 levels in patients to enhance the effectiveness of $\beta 2$-agonists. Long-acting $\beta 2$-agonists such as formoterol do not have the same desensitizing properties as short-acting agonists[13]. This concept is further supported in our current study in that ADRB2 expression was significantly decreased by approximately 2-fold in (R)-albuterol-treated bronchial epithelial cells compared to negative controls $(p=0.045)$, but there was no difference between $(R, R)$-formoteroltreated cells and negative controls. Although further mechanistic studies are needed to reveal the interplay among short-acting $\beta 2$-agonists such as (R)-albuterol, ADRB2, Mp load and SPLUNC1, our current study suggests that the use of a long-acting $\beta 2$-agonist may not only induce bronchodilation, but also increase airway epithelial innate immunity in patients with a lung disease such as asthma.

\section{Competing interests \\ The authors declare that they have no competing interests.}

\section{Authors' contributions}

CAG, ARW and RMG performed airway epithelial cell cultures, ELISA and PCR. RBP did the bronchoscopy and bronchial brushings. HWC is the principal investigator of the research projects, and develop the research ideas and experimental design. CAG, RBP and HWC were involved in manuscript writing and editing. All authors read and approved the final manuscript.

\section{Acknowledgements}

This work was supported by the Flight Attendant Medical Research Institute (FAMRI), Sepracor, Inc., and National Institutes of Health (NIH) grant RO1 HL088264

\section{Author Details}

1Department of Medicine, National Jewish Health, 1400 Jackson Street, Denver, Colorado, 80206, USA and 2University of Colorado-Denver, 12800 E. 19th Avenue, Aurora, Colorado, 80045, USA

Received: 29 September 2009 Accepted: 14 May 2010 Published: 14 May 2010

\section{References}

1. Wu L, Skinner SJM, Lambie N, Vuletic JC, Blasi R, Black PN: Immunohistochemical staining for Chlamydia pneumoniae is increased in lung tissue from subjects with chronic obstructive pulmonary disease. Am J Respir Crit Care Med 2000, 162:1148-1151.

2. Emre U, Roblin PM, Gelling M, Dumornay W, Rao M, Hammerschlag MR, Schachter J: The association of Chlamydia pneumoniae infection and reactive airway disease in children. Arch Pediatr Adolesc Med 1994, 148:727-732.

3. Hahn DL, Dodge RW, Golubjatnikov R: Association of Chlamydia pneumoniae (strain TWAR) infection with wheezing, asthmatic bronchitis, and adult-onset asthma. JAMA 1991, 266:225-230.

4. Martin RJ, Kraft M, Chu HW, Berns EA, Cassell GH: A link between chronic asthma and chronic infection. J Allergy Clin Immunol 2001, 107:595-601.

5. ten Brinke A, Dissel JT, Sterk PJ, Zwinderman AH, Rabe KF, Bel EH: Persistent airflow limitation in adult-onset nonatopic asthma is 
associated with serologic evidence of Chlamydia pneumoniae infection. J Allergy Clin Immunol 2001, 107:449-454.

6. Blasi F, Damato S, Cosentini R, Tarsia P, Raccanelli R, Centanni S, Allegra L: Chlamydia pneumoniae and chronic bronchitis: association with severity and bacterial clearance following treatment. Thorax 2002, 57:672-676.

7. Kraft M, Cassell GH, Pak J, Martin RJ: Mycoplasma pneumoniae and Chlamydia pneumoniae in asthma. Chest 2002, 121:1782-1788.

8. LeClair EE: Four BPI (bacterial/permeability-increasing protein)-like genes expressed in the mouse nasal, oral, airway and digestive epithelia. Biochem Soc Trans 2003, 31:801-805.

9. Zhou HD, Li XL, Li GY, Zhou M, Liu HY, Yang YX, Deng T, Ma J, Sheng SR: Effect of SPLUNC1 protein on the Pseudomonas aeruginosa and Epsterin-Barr virus. Mol Cell Biochem 2008, 309:191-197.

10. Chu HW, Thaikoottathil J, Rino JG, Zhang G, Wu Q, Moss T, Refaeli Y, Bowler R, Wenzel S, Chen Z, Zdunek J, et al:: Function and regulation of SPLUNC1 protein in Mycoplasma infection and allergic inflammation. J Immunol 2007, 179:3995-4002

11. Kao CY, Chen Y, Thai P, Wachi S, Huang F, Kim C, Harper R, Wu R: IL-17 markedly up-regulates $\beta$-Defensin-2 expression in human airway epithelium via JAK and NF-KB signaling pathways. J Immunol 2004, 173:3482-3491

12. Kisich KO, Carspecken CW, Fieve S, Boguniewicz M, Leung DY: Defective killing of Staphylococcus aureus in atopic dermatitis is associated with reduced mobilization of human beta-defensin-3. J Allergy Clin Immunol 2008, 122:62-68.

13. Johnson M: The $\beta$-adrenoceptor. Am J Respir Crit Care Med 1998, 158:S146-S153.

14. Barnes PJ: Beta-adrenergic receptors and their regulation. Am J Respir Crit Care Med 1995, 152:838-860.

15. Izeboud CA, Monshouwer M, van Miert AS, Witkamp RF: The betaadrenoceptor agonist clenbuterol is a potent inibitor of the LPSinduced production of TNF-alpha and IL-6 in vitro and in vivo. Inflamm Res 1999, 48:497-502.

16. Coraux C, Kileztky C, Polette M, Hinnrasky J, Zahm JM, Devillier P, De Bentzmann S, Puchelle E: Airway epithelial integrity is protected by a long-acting $\beta 2$-adrenergic receptor agonist. Am J Respir Cell Mol Biol 2004, 30:605-612.

17. Loza MJ, Foster S, Peters SP, Penn RB: Beta-agonists modulate T-cell functions via direct actions on type 1 and type 2 cells. Blood 2006 107:2052-2060

18. Reinero CR, Delgado C, Spinka C, DeClue A, Dhand R: Enantiomer-specific effects of albuterol on airway inflammation in healthy and asthmatic cats. Int Arch Allergy Immunol 2009, 150:43-50.

19. Baramki D, Koester J, Anderson AJ, Borish L: Modulation of T-cell function by (R)- and (S)-isomers of albuterol: Anti-inflammatory influences of (R)-isomers are negated in the presence of the (S)-isomer. J Allergy Clin Immunol 2002, 109:449-454.

20. Gross CA, Green RM, Weinberger AR, Bowler RP, Chu HW: (R)-albuterol and $(R, R)$-formoterol promote airway epithelial defense against bacterial infection [abstract]. Am J Respir Crit Care Med 2009, 179:A4974

21. Chu HW, Balazar S, Seedorf GJ, Westcott JY, Trudeau JB, Silkoff P, Wenzel SE: Transforming growth factor- $\beta 2$ induces bronchial epithelial mucin expression in asthma. Am J Pathol 2004, 165:1097-1106.

22. Xiang J, Rir-Sim-Ah J, Tesfaigzi Y: IL-9 and IL-13 induce mucous cell metaplasia that is reduced by IFN- $\gamma$ in a Bax-mediated pathway. Am Respir Cell Mol Biol 2008, 38:310-317.

23. Yeh TH, Lee SY, Hsu WC: Expression of SPLUNC1 protein in nasal polyp epithelial cells in air-liquid interface culture treated with IL-13. Am J Rhinol Allergy 2010, 24:17-20.

24. Batra V, Musani Al, Hastie AT, Khurana S, Carpenter KA, Zangrilli JG, Peters SP: Bronchoalveolar lavage fluid concentrations of transforming growth factor (TGF)- $\beta 1$, TGF- $\beta 2$, interleukin (IL)- 4 and IL-13 after segmental allergen challenge and their effects on alpha-smooth muscle actin and collagen III synthesis by primary human lung fibroblasts. Clin Exp Allergy 2004, 34:437-444

25. Chorley BN, Li Y, Fang S, Park JA, Adler KB: (R)-albuterol elicits antiinflammatory effects in human airway epithelial cells via iNOS. Am J Respir Cell Mol Biol 2006, 34:119-127.

26. Tse R, Marroquin BA, Dorscheid DR, White SR: Beta-adrenergic agonists inhibit corticosteroid-induced apoptosis of airway epithelial cells. Am J Physiol Lung Cell Mol Physiol 2003, 285:L393-404.
27. Atabai K, Ware LB, Snider ME, Koch P, Daniel B, Nuckton TJ, Matthay MA: Aerosolized $\beta 2$-adrenergic agonists achieve therapeutic levels in the pulmonary edema fluid of ventilated patients with acute respiratory failure. Intensive Care Med 2002, 28:705-711.

28. Zhang Y, Reenstra WW, Chidekel A: Antibacterial activity of apical surface fluid from the human airway cell line Calu-3: pharmacologic alteration by corticosteroids and beta(2)-agonists. Am J Respir Cell Mol Biol 2001, 25:196-202.

29. Kaur M, Chivers JE, Giembycz MA, Newton R: Long-acting $\beta 2$ adrenoceptor agonists synergistically enhance glucocorticoiddependent transcription in human airway epithelial and smooth muscle cells. Mol Pharmacol 2008, 73:203-214.

30. Strandberg K, Palmberg L, Larsson K: Effect of formoterol and salmeterol on IL-6 and IL-8 release in airway epithelial cells. Respir Med 2007, 101:1132-1139.

31. Thaikoottathil JV, Martin RJ, Zdunek J, Weinberger A, Rino JG, Chu HW: Cigarette smoke extract reduces VEGF in primary human airway epithelial cells. Eur Respir J 2009, 33:835-843.

32. Anderson GP: Endotyping asthma: new insights into key pathogenic mechanisms in a complex, heterogeneous disease. Lancet 2008, 372:1107-1119.

33. Woodruff PG, Modrek B, Choy DF, Jia G, Abbas AR, Ellwanger A, Koth LL, Arron JR, Fahy JV: Th2-driven inflammation defines major subphenotypes of asthma. Am J Respir Crit Care Med 2009, 180:388-395.

34. Kraft M, Adler KB, Ingram JL, Crews AL, Atkinson TP, Cairns CB, Krause DC, Chu HW: Mycoplasma pneumoniae induces airway epithelial cell expression of MUC5AC in asthma. Eur Respir J 2008, 31:43-46.

35. Hasani A, Toms N, Agnew JE, Lloyd J, Dilworth JP: Mucociliary clearance in COPD can be increased by both a D2/ $\beta 2$ and a standard $\beta 2$ agonists. Respir Med 2005, 99:145-151.

36. Dowling RB, Johnson M, Cole PJ, Wilson R: Effect of fluticasone propionate and salmeterol on Pseudomonas aeruginosa infection of the respiratory mucosa in vitro. Eur Respir J 1999, 14:363-369.

37. Ibe BO, Abdallah MF, Raj JU: Mechanisms by which S-albuterol induces human bronchial smooth muscle cell proliferation. Int Arch Allergy Immunol 2008, 146:321-333.

38. Maris NA, Florquin $S$, van't Veer C, de Vos AF, Buurman W, Jansen HM, Poll $T$ van der: Inhalation of $\beta 2$ agonists impairs the clearance of nontypeable Haemophilus influenzae from the murine respiratory tract. Respir Res 2006, 7:57.

\section{Pre-publication history}

The pre-publication history for this paper can be accessed here: http://www.biomedcentral.com/1471-2466/10/30/prepub

doi: $10.1186 / 1471-2466-10-30$

Cite this article as: Gross et al., ?2-agonists promote host defense against bacterial infection in primary human bronchial epithelial cells BMC Pulmonary Medicine 2010, 10:30

\section{Submit your next manuscript to BioMed Centra and take full advantage of:}

- Convenient online submission

- Thorough peer review

- No space constraints or color figure charges

- Immediate publication on acceptance

- Inclusion in PubMed, CAS, Scopus and Google Scholar

- Research which is freely available for redistribution 